\title{
TROFIČKE KARAKTERISTIKE I UTJECAJ BUKOVE SKOČIPIPE NA POVRŠINU OŠTEĆENJA LISTA BUKVE U BOSNI I HERCEGOVINI
}

\author{
TROPHIC PREFERENCES AND INFLUENCE OF BEECH WEEVIL \\ ON THE DAMAGED LEAF AREA OF BEECH TREES IN BOSNIA \\ AND HERZEGOVINA
}

Osman MUJEZINOVIĆ ${ }^{1}$, Kenan ZAHIROVIĆ ${ }^{\text {, Milivoj FRANJEVIĆ }}{ }^{3}$, Mirza DAUTBAŠIĆ ${ }^{1}$

\begin{abstract}
SAŽETAK
Bukva predstavlja jednu od najvažnijih vrsta drveća u Bosni i Hercegovini. Stoga, potrebno je praćenje zdravstvenog stanja bukovih sastojina i poduzimanje svih neophodnih preventivnih i represivnih mjera kako bi se zdravstveno stanje ovih sastojina unaprijedilo. U okviru istraživanja analiziran je utjecaj bukove skočipipe na površinu oštećenja listova na stabalcima bukve od imaga i ličinke u ovisnosti od lokacije i položaja stabalaca bukve u sastojini (svjetlo/sjena). Lokacije istraživanja su se nalazile unutar kulture smreke, visokih šuma bukve i mješovitih šuma bukve i jele sa smrekom. Bukova skočipipa predstavlja jednog od glavnih defolijatora koji se javljaju na stablima bukve. Uzorak istraživanja čine 15 stabalaca bukve, po 5 stabalaca na tri lokacije. Na svakoj lokaciji odabrana su 3 stabalca čija krošnja je bila na svjetlu i dva stabalca čija krošnja je bila u sjeni (ukupno 9 stabalaca na svjetlu i 6 stabalaca u zasjeni). Na svakom stablu pregledavana su i mjerena oštećenja od imaga i ličinke bukove skočipipe. Ustanovljeno je da prosječna površina oštećenja lista bukve od imaga je varirala od 2-4\%, a ličinke od 4-8\%. Statističkim analizama je utvrđeno postojanje statistički značajnih razlika u površini oštećenja lista bukve od ličinke u ovisnosti od položaja stabalaca bukve u sastojini.
\end{abstract}

KLJUČNE RIJEČI: Fagus sylvatica, Rhynchaenus fagi, površina oštećenja, lokacija, svjetlo, sjena.

\section{UVOD}

\section{INTRODUCTION}

Insekti koji uzrokuju defolijaciju su jedan od najvažnijih uzročnika slabljenja zdravstvenog stanja šuma, mogu uzrokovati značajne gubitke drveta, a u određenim uvjetima i sušenje stabala (Fleming i Volney 1995; Fraser i Latifovic 2005). Najznačajniji defolijator na bukvi je bukvina skočipipa, na kojoj vrši svoj larvalni razvoj (Pullin 1981). Kao i kod drugih vrsta, monitoring defolijacije bukvine skočipipe Rhynchae- nus fagi L. (Coleoptera: Curculionidae) se najčešće obavlja vizualno i kako je često subjektivna nužno je uzeti u obzir trofičke karakteristike bukvine skočipipe (Seletković i Potočić 2004). Kao jedna od najraširenijih vrsta listača u Evropi, bukva (Fagus sylvatica L.) je i vrlo često stanište za brojne ugrožene vrste (Ballian i dr. 2015). Bukova skočipipa se javlja na vrstama iz roda Fagus, najčešće na mlađim stablima i najvažniji je defolijator bukve (Rullán-Silva i dr. 2015). Najčešće izaziva samo štete estetske prirode, ali može biti zami-

\footnotetext{
1 Prof. dr. sc. Osman Mujezinović, Prof. dr. sc. Mirza Dautbašić, Faculty of Forestry, University of Sarajevo, Zagrebačka 20, 71000 Sarajevo, Bosnia and Herzegovina.E-mail: osmansfs@yahoo.com,mirzad@bih.net.ba

2 Dr. sc. Kenan Zahirović, Public enterprise „Šumsko-privredno društvo Zeničko-dobojskog kantona“ d.o.o Zavidovići, Alije lzetbegovića 25, 72220 Zavidovići, Bosnia and Herzegovina. E-mail: zahirovic_kenan@yahoo.com

3 Doc. dr. sc. Milivoj Franjević, Department of Forest Protection and Wildlife Management, University of Zagreb, Faculty of Forestry, Svetošimunska 25, 10002

Zagreb, Croatia. E-mail: milivoj.franjevic@sumfak.hr
} 

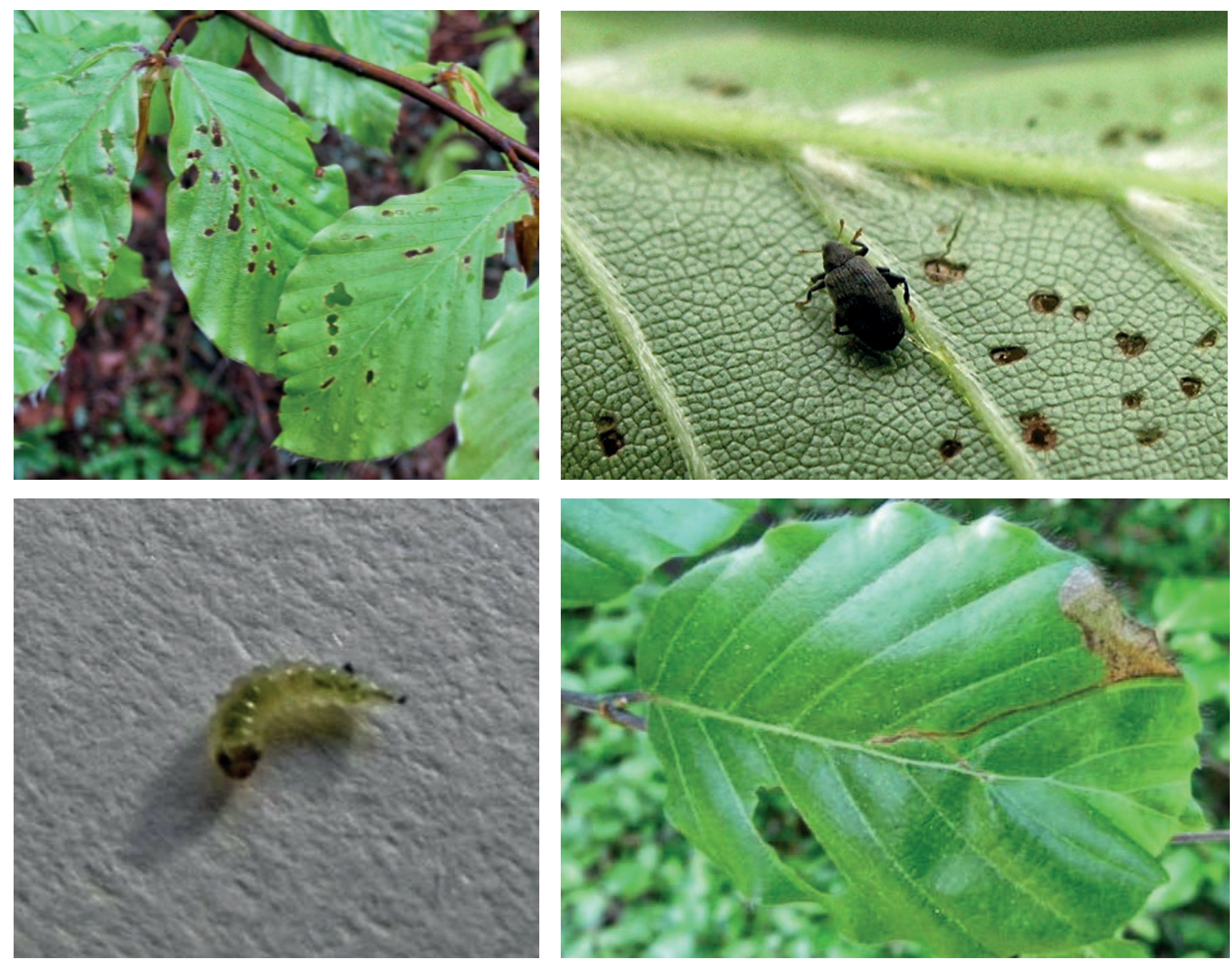

Slike 1-4. Rhynchaenus fagi, rupice nastale žderanjem imaga (original), imago (autor: Boris Hrašovec), ličinka (original) i smeđenje lista usljed hranjenja ličinke parenhimom lista (original)

Pictures 1-4. Rhynchaenus fagi, holes formed after feeding of adult (original), adult (author: Boris Hrašovec), larvae (original) and browning of leaf due the feeding of larvae within the leaf parenchym (original)

jenjena za druge abiotičke čimbenike poput kasnog mraza, a moguće su i značajne štete kada se poklope uvjeti za to (Dimitrova-Mateva i dr. 2016). U proljeće se na listovima bukve pojavljuju grizotine okruglastog oblika po cijeloj površini lisne plojke koje uzrokuju odrasle jedinke žderanjem (Slika 1). Imago je crne, crnosmeđe boje, veličine 2-3 mm (Slika 2). Ima posebno zadebljale stražnje noge dajući im veliku sposobnost za skakanje (odatle i naziv). Ličinka je bijele boje sa tamnom glavom, koja vijugavo minira list od središnje lisne žile do postranih žila (Slika 3). Ti dijelovi tijekom mjeseca lipnja posmeđe (Slika 4) (Metzler i Bublitz 2004; Tomiczek i dr. 2007; Hartmann i dr. 2007; Zúbrik i dr. 2013). Ima jednu generacije godišnje. Prezimljava u stadiju imaga u tlu ili u pukotinama kore. Imaga se javljaju u travnju ili svibnju i žderanjem umanjuju aktivnu lisnu površinu. U svibnju ženka polaže 30-35 jaja u blizini središnje žile, na svaki list najčešće polaže po jedno jaje (ponekad dva ili tri). Nakon dva tjedna javlja se ličinka koja minira list, a u tom stadiju ličinke se hrane parenhimom lista 5 tjedana (Metzler i Bublitz 2004; Schardt i dr. 2006; Tomiczek i dr. 2007; Hartmann i dr. 2007; Zúbrik i dr. 2013).

Cilj ovog rada je utvrditi trofičke karakteristike i ekološki utjecaj bukove skočipipe unutar različitih tipova sastojina u kojima bukva sudjeluje u omjeru smjese u Bosni i Hercegovini.

\section{MATERIJALI I METODE ISTRAŽIVANJA MATERIALS AND METHODS OF RESEARCH}

Istraživanje je rađeno tijekom 2017. godine na 15 stabalaca bukve maksimalne visine do $2 \mathrm{~m}$ koji čine uzorak za analizu trofičkih značajki bukvine skočipipe. Odabrane su različite lokacije (centralni dio Bosne i Hercegovine) u tri različite sastojine u kojima se javlja bukva (različito učešće bukve u omjeru smjese): i) lokacija 1 - narodni naziv Ravne: gospodarska jedinica „Donja Stavnja“, odjel 61 - kultura smreke, nadmorska visina $880 \mathrm{~m}$, ekspozicija sjever; ii) lokacija 2 - narodni naziv Suhodol: gospodarska jedinica „Donja Stavnja“, odjel 57 - planinska šume bukve, nadmor- 


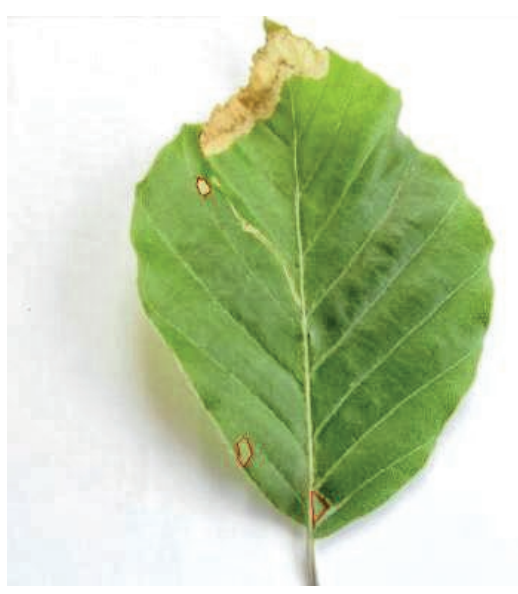

Slike 5-6. Površina oštećenja lista nastalih žderanjem imaga i ličinke Pictures 5-6. Damages of leaf area formed after feeding of adult and larvae

ska visina 830 m, ekspozicija zapad; iii) lokacija 3 - narodni naziv Ponikva: gospodarska jedinica „Gornja Stavnja“, odjel 30 - mješovite šume bukve i jele sa smrekom, nadmorska visina $1090 \mathrm{~m}$, ekspozicija jug. Sa svake lokacije odabrano je po 5 stabala sa kojih su uzimani uzorci, a prijenosnim mikroskopom SVP DM540 praćen je razvoj (bionomija) bukove skočipipe po razvojnim stadijima. Nadalje je analizirana površina listova i površina defolijacije pomoću programskog alata WinGis (ver. 2010) metodom planimetriranja (Morrison i Tainton 1993). Sa svakog stabla metodom slučajnog uzorka svakih 15 dana su uzimana po tri lista (na donjem, srednjem i gornjem dijelu stabalca, te je za analizu izračunat prosjek) s oštećenjima od imaga i ličinke (ukupno 315 listova). Skeniranjem listova utvrđivana je površina lista u omjeru 1:1, te površina oštećenja na listu koja je nastala žderanjem imaga i površina oštećenja lista koja je nastala usljed žderanja ličinke (Slike 5 i 6). Površina oštećenja listova od imaga nije ispitivana u periodu od 1.6.-1.7. jer je

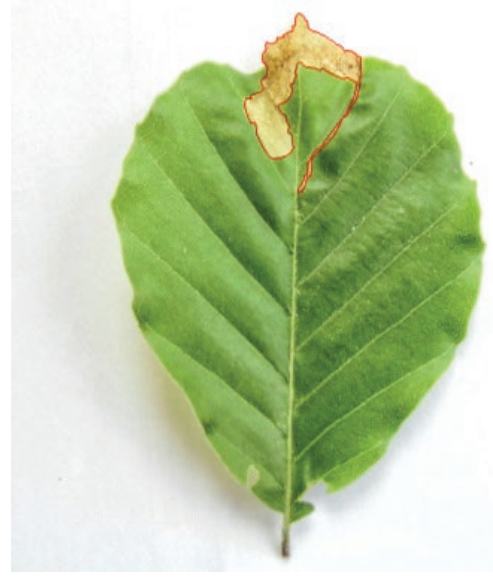

štetnik tada bio u stadiju ličinke i kukuljice, a oštećenja koja su pronađena na listovima su nastala u periodu 1.5.-15.5.

Istraživana je bionomija razvoja bukove skočipipe na sve tri lokacije praćenjem razvojnih stadijuma, kao i utjecaj lokacije na površinu oštećenja listova od imaga i ličinke, te utjecaj položaja stabalaca bukve u sastojini, odnosno stabla svjetla ili sjene u odnosu na površinu nastalih oštećenja (analizom varijance). Pri analizi je korišten softver SPSS (ver. 20) i testiranje statističke značajnosti prosjeka (ANOVA) i diskriminacione analize.

\section{REZULTATI RESULTS}

Utvrđivana je bionomija bukove skočipipe na sve tri lokacije (Tablica 1).

Bionomija bukove skočipipe na lokaciji 3 odstupa 15 dana (1 mjerenje) (Tablica 1). Regresijska analiza prosječne po-

Tablica 1. Kalendar razvoja bukove skočipipe za različite lokacije

Table 1. Life cycle stages of beech weevil for different localities

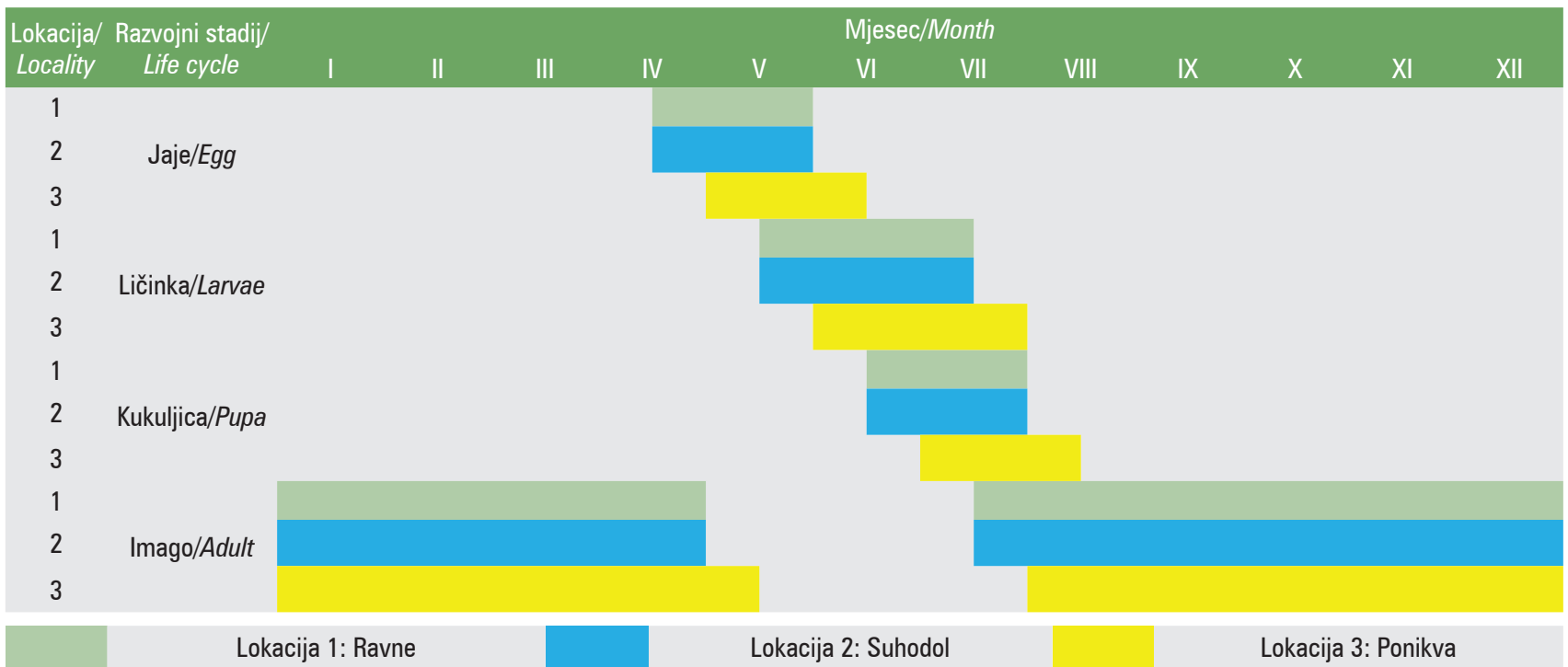




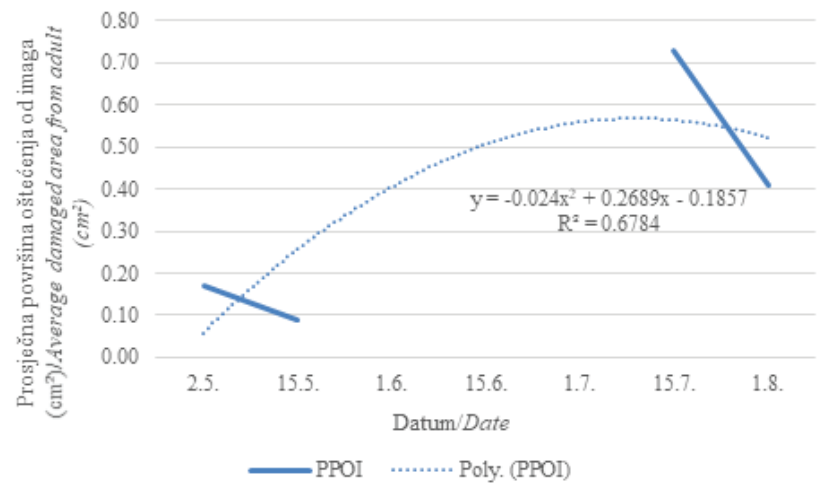

Grafikon 1. Regresiona analiza prosječne površine oštećenja listova od imaga (PPOI)

Figure 1. Regression analysis of average damaged leaf area from adult (PPOI)

Tablica 2. Aritmetička sredina i standardna devijacija za površinu lista, površinu oštećenja lista od imaga i ličinke bukove skočipipe za različite lokacije

Table 2. Arithmetic mean and standard deviation of leaf area, damaged leaf area from adult and larvae of beech weevil for different localities

\begin{tabular}{|c|c|c|c|c|}
\hline Lokacij & a/Locality & $\begin{array}{l}\text { Površina lista } \\
\qquad\left(\mathrm{cm}^{2}\right) /\end{array}$ & $\begin{array}{c}\text { Površina } \\
\text { oštećenja } \\
\text { lista-imago } \\
\left(\mathrm{cm}^{2}\right) /\end{array}$ & $\begin{array}{c}\text { Površina } \\
\text { oštećenja } \\
\text { lista-ličinka } \\
\left(\mathrm{cm}^{2}\right) /\end{array}$ \\
\hline & & $\left(\mathrm{cm}^{2}\right)$ & $\begin{array}{l}\text { Damaged leaf } \\
\text { area-adult }\left(\mathrm{cm}^{2}\right)\end{array}$ & $\begin{array}{c}\text { Damaged leaf } \\
\text { area-larvae }\left(\mathrm{cm}^{2}\right)\end{array}$ \\
\hline & Mean & 12.312 & 0.346 & 1.002 \\
\hline 1 & $\mathrm{~N}$ & 5 & 5 & 5 \\
\hline & $\begin{array}{c}\text { Std. } \\
\text { Deviation }\end{array}$ & 1.124 & 0.193 & 0.096 \\
\hline & Mean & 14.046 & 0.358 & 0.676 \\
\hline 2 & N & 5 & 5 & 5 \\
\hline & $\begin{array}{c}\text { Std. } \\
\text { Deviation }\end{array}$ & 1.577 & 0.142 & 0.281 \\
\hline & Mean & 13.832 & 0.566 & 1.032 \\
\hline 3 & $\mathrm{~N}$ & 5 & 5 & 5 \\
\hline & $\begin{array}{c}\text { Std. } \\
\text { Deviation }\end{array}$ & 3.248 & 0.265 & 0.427 \\
\hline & Mean & 13.396 & 0.423 & 0.903 \\
\hline Ukupno/ & $\mathrm{N}$ & 15 & 15 & 15 \\
\hline & $\begin{array}{c}\text { Std. } \\
\text { Deviation }\end{array}$ & 2.173 & 0.217 & 0.324 \\
\hline
\end{tabular}

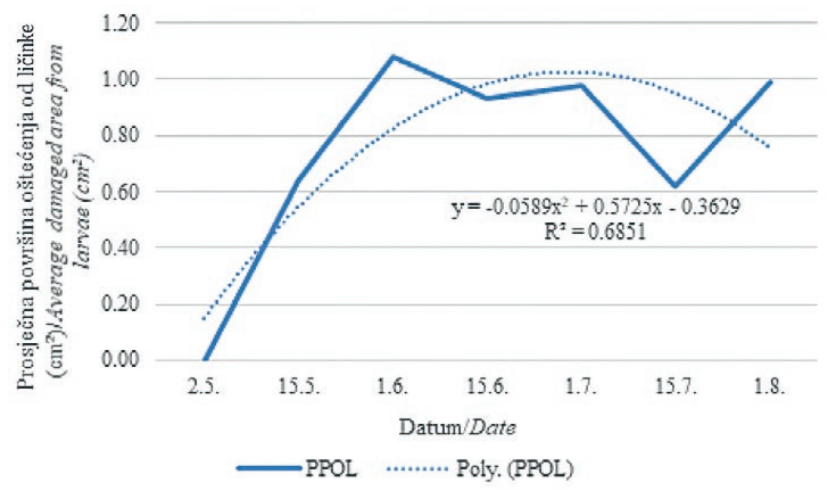

Grafikon 2. Regresiona analiza prosječne površine oštećenja lista od ličinke (PPOL)

Figure 2. Regression analysis of average damaged leaf area from larvae (PPOL)

vršine oštećenja lista od imaga i ličinke rađena je prema datumu mjerenja za sve tri lokacije zajedno (Grafikoni 1 i 2).

U cilju analize utjecaja lokacije na površinu oštećenja lista od imaga $\mathrm{i}$ ličinke bukove skočipipe provedeno je testiranje statističke značajnosti razlika prosjeka. U Tablici 2 je prikazana aritmetička sredina i standardna devijacija za površinu lista, površinu oštećenja lista od imaga i ličinke na različitim lokacijama. U Tablici 3 je prikazana analiza varijance za utjecaj lokacije na površinu oštećenja lista od imaga i ličinke.

Provedenim analizama nije utvrđen statistički značajan utjecaj lokacije na površinu oštećenja lista od imaga i ličinke $(\mathrm{p}>0.05)$. Za utvrđivanja utjecaja lokacije na površinu oštećenja provedena je diskriminacijska analiza, a cilj je bio utvrditi koje se karakteristike površina oštećenja lista od imaga i ličinke mogu grupirati. Rezultati istraživanja su prikazani na Grafikonu 3.

Na osnovi Grafikona 3 i položaja centroida može se zaključiti da postoje 2 podgrupe, koje su razdvojene na osnovi diskriminacijskih funkcija, odnosno dvije grupe koje se razlikuju po površini oštećenja lista od imaga i ličinke. Vidimo da podgrupu 1 čine lokacija 2 (gospodarska jedinica „Donja Stavnja“, odjel 57), dok podgrupu 2 čine lokacije 1 i 3 (gospodarska jedinica „Donja Stavnja“, odjel 61; gospodarska jedinica „Gornja Stavnja“, odjel 30), što je bilo i za

Tablica 3. ANOVA-utjecaj lokacije na površinu oštećenja lista od imaga i ličinke

Table 3. ANOVA-impact of the locality on the damaged leaf area from adult and larvae

\begin{tabular}{|c|c|c|c|c|c|c|}
\hline & & ANOVA Table & & & & \\
\hline & & Sum of Squares & df & Mean Square & $\mathrm{F}$ & Sig. \\
\hline Površina oštećenja lista-imago * & Between Groups(Combined) & 0.153 & 2 & 0.077 & 1.793 & 0.208 \\
\hline Lokacija / Damaged leaf & Within Groups & 0.512 & 12 & 0.043 & & \\
\hline area-adult * Locality & Total & 0.665 & 14 & & & \\
\hline Površina oštećenja lista-ličinka * & Between Groups(Combined) & 0.390 & 2 & 0.195 & 2.157 & 0.158 \\
\hline Lokacija / Damaged leaf & Within Groups & 1.084 & 12 & 0,090 & & \\
\hline area-larvae * Locality & Total & 1.474 & 14 & & & \\
\hline
\end{tabular}




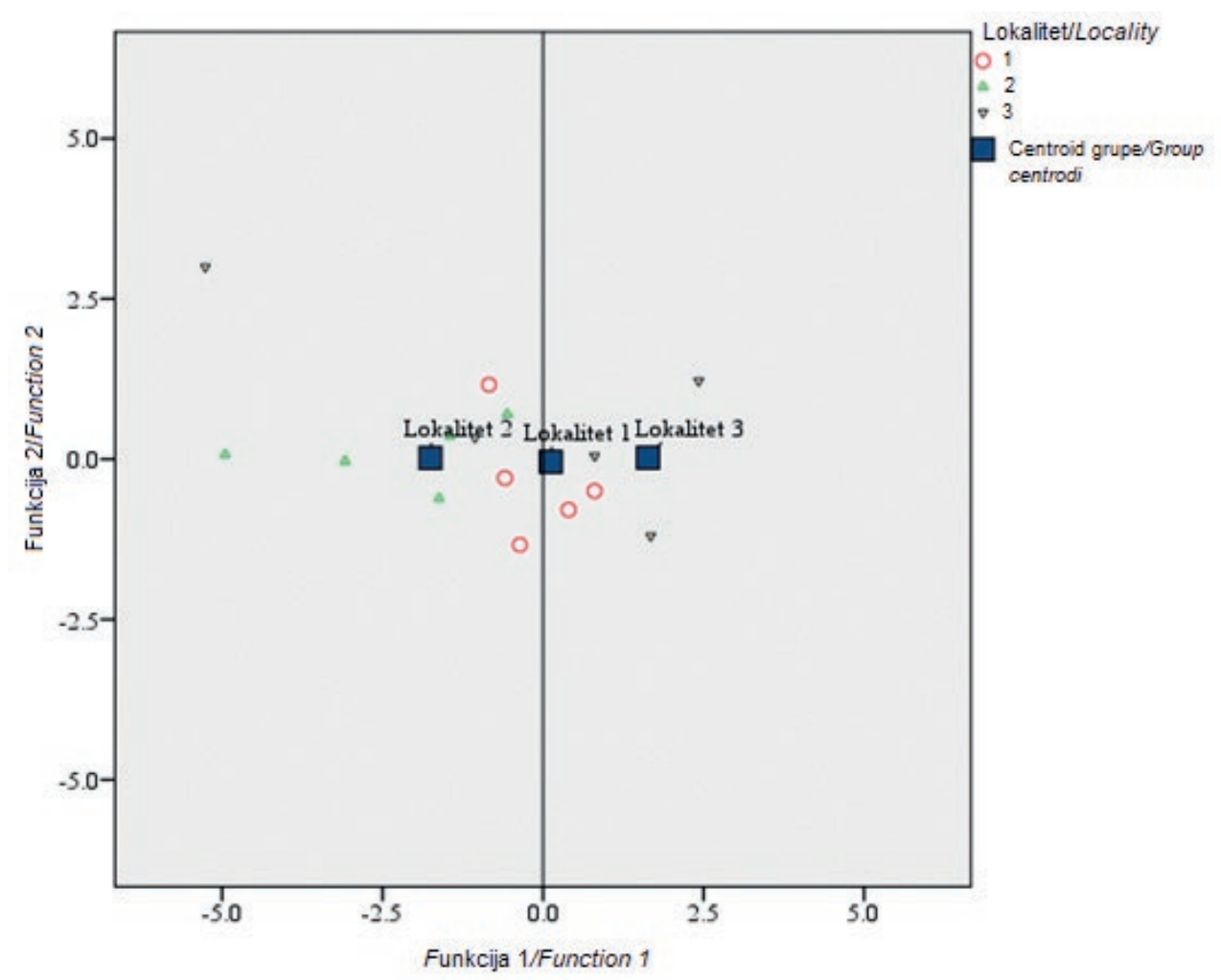

Grafikon 3. Grupiranje kod kanoničke diskriminantne analize

Figure 3. Grouping by canonical discriminatory analysis

Tablica 4. Aritmetička sredina i standardna devijacija za površinu lista, površinu oštećenja lista od imaga i ličinke bukove skočipipe u odnosu na položaj stabalaca bukve u sastojini

Table 4. Arithmetic mean and standard deviation of leaf area, damaged leaf area from adult and larvae of beech weevil in relation to the position of the beech tree in the stand

\begin{tabular}{|c|c|c|c|c|}
\hline \multirow{2}{*}{\multicolumn{2}{|c|}{$\begin{array}{l}\text { Položaj stabalaca/ } \\
\text { Position of tree }\end{array}$}} & \multirow{2}{*}{$\begin{array}{l}\text { Površina } \\
\text { lista }\left(\mathrm{cm}^{2}\right) / \\
\text { Leaf area } \\
\left(\mathrm{cm}^{2}\right)\end{array}$} & \multirow{2}{*}{$\begin{array}{c}\text { Površina } \\
\text { oštećenja } \\
\text { lista-imago } \\
\left(\mathrm{cm}^{2}\right) / \\
\text { Damaged leaf } \\
\text { area-adult }\left(\mathrm{cm}^{2}\right)\end{array}$} & \multirow{2}{*}{$\begin{array}{c}\text { Površina } \\
\text { oštećenja } \\
\text { lista-ličinka } \\
\left(\mathrm{cm}^{2}\right) / \\
\text { Damaged leaf } \\
\text { area-larvae }\left(\mathrm{cm}^{2}\right)\end{array}$} \\
\hline & & & & \\
\hline \multirow{4}{*}{$\begin{array}{l}\text { Svjetlo/ } \\
\text { Sun }\end{array}$} & Mean & 12.422 & 0.427 & 1.040 \\
\hline & $\mathrm{N}$ & 9 & 9 & 9 \\
\hline & $\begin{array}{c}\text { Std. } \\
\text { Deviation }\end{array}$ & 1.297 & 0.201 & 0.274 \\
\hline & Mean & 14.858 & 0.416 & 0.698 \\
\hline \multirow{3}{*}{$\begin{array}{l}\text { Sjena/ } \\
\text { Shade }\end{array}$} & $\mathrm{N}$ & 6 & 6 & 6 \\
\hline & $\begin{array}{c}\text { Std. } \\
\text { Deviation }\end{array}$ & 2.503 & 0.260 & 0.300 \\
\hline & Mean & 13.396 & 0.423 & 0.903 \\
\hline \multirow{2}{*}{$\begin{array}{c}\text { Ukupno/ } \\
\text { Total }\end{array}$} & $\mathrm{N}$ & 15 & 15 & 15 \\
\hline & $\begin{array}{c}\text { Std. } \\
\text { Deviation }\end{array}$ & 2.173 & 0.217 & 0.324 \\
\hline
\end{tabular}

očekivati, jer u 1 podgrupi se radi o visokim šumama bukve, a u 2 podgrupi o kulturi smreke i mješovitim šumama bukve i jele sa smrekom. Ukoliko promatramo površinu oštećenja lista od ličinke, vidi se da su one izvan visokih šuma bukve veće, jer se radi o mješovitim šumama, i zbog nedostatka stabala bukve usljed prenamnoženja ovog štetnika napadnut je veći broj listova na tim stablima. U Tablici 4 je prikazana aritmetička sredina i standardna devijacija za površinu lista, površinu oštećenja lista od imaga i ličinke u odnosu na položaj stabalaca bukve u sastojini. U Tablici 5 je prikazana analiza varijance za utjecaj položaja stabalaca na površinu oštećenja lista od imaga i ličinke.

Provedenim analizama je utvrđen statistički značajan utjecaj položaja stabalaca u sastojini na površinu oštećenja lista od ličinke ( $\mathrm{p}<0.05)$, a nije utvrđen statistički značajan utjecaj položaja stabalaca u sastojini na površinu oštećenja lista od imaga ( $\mathrm{p}>0.05)$.

\section{RASPRAVA DISCUSSION}

Ovim istraživanjem obuhvaćene su trofičke karakteristike bukvine skočipipe i različiti indikatori napada. Fokus istraživanja bila je analiza utjecaja lokacije i položaja stabalaca bukve u sastojini na površinu oštećenja lista od imaga i ličinke. Značaj ovog istraživanja se ogleda u analizi položaja stabalaca bukve u sastojini na površinu oštećenja, a koje je prvi put analizirano za uvjete Bosne i Hercegovine.

Istraživanjem je obuhvaćeno 15 stabalaca bukve, a koja su odabrana tako da je 9 stabalaca bilo izravno izloženo svjetlu, a 6 stabalaca bilo u zasjeni. Istraživanjem je utvrđeno 
Tablica 5. ANOVA-utjecaj položaja stabalaca u sastojini na površinu oštećenja lista od imaga i ličinke Table 5. ANOVA-impact of the position of tree in stand on the damaged leaf area from adult and larvae

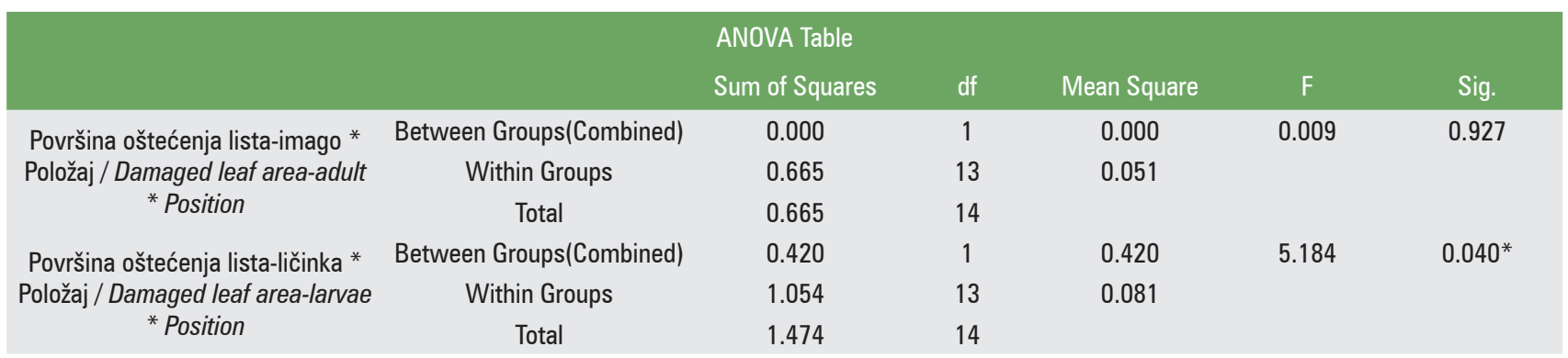

da bionomija bukove skočipipe odstupa 15 dana na lokaciji 3 u odnosu na ostale dvije lokacije, i to zbog nadmorske visine lokacije (kašnjenje vegetacionog perioda) (Tablica 1). Prosječna površina oštećenja lista od imaga je znatno veća u novoj (ovogodišnjoj) generaciji, dok prosječna površina oštećenja lista od ličinke progresivno raste do mjeseca lipnja, kada počinje blago opadati (Grafikoni 1 i 2). U cilju analize utjecaja lokacije na površinu oštećenja lista od imaga i ličinke bukove skočipipe provedeno je testiranje statističke razlike prosjeka. Utvrđeno je da je prosječna površina oštećenja lista od imaga u odnosu na prosječnu površinu lista najveća na lokaciji 3, a prosječna površina oštećenja lista od ličinke na lokaciji 1. Ukoliko se promatraju ova dva oštećenja, vidljivo je da je u prosjeku od bukove skočipipe oštećeno preko $10 \%$ lisne površine stabalaca bukve. Prema istraživanjima koja je provela Dimitrova-Mateva (2008) u Bugarskoj, ovaj štetnik može izazvati defolijaciju čak i do $78 \%$ lisne površine stabala bukve. Od toga imago uzrokuje oštećenja do 20\% lisne površine, a 58\% ličinka. Dosadašnja istraživanja pokazuju da defolijacija listova od ovog štetnika rijetko prelazi 30\% (Dimitrova-Mateva 2005; 2008; Dimitrova-Mateva i dr. 2016). Rezultati koji su dobiveni istraživanjima u Bugarskoj pokazuju da su oštećenja listova od bukvine skočipipe znatno veća nego u Bosni i Hercegovini. Utvrđivan je utjecaj lokacije stabalaca bukve na površinu oštećenja lista od imaga i ličinke. Provedenim analizama nije utvrđen statistički značajan utjecaj lokacije na površinu oštećenja lista od imaga i ličinke, a kako su lokacije bile na različitim nadmorskim visinama i ekspozicijama, možemo zaključiti da nije utvrđen statistički značajan utjecaj nadmorske visine i ekspozicije na površinu oštećenja lista od imaga i ličinke.

Za utvrđivanja utjecaja lokacije na površinu oštećenja provedena je diskriminacijska analiza (Grafikon 3). Grupiranjem na osnovi diskriminacijske analize i položaja centroida utvrđene su dvije podgrupe. Na osnovi toga dobiveno je da su površine oštećenja lista od imaga i ličinke izvan visokih šuma bukve veće, jer se radi o mješovitim šumama, te je zbog nedostatka stabala bukve usljed prenamnoženja ovog štetnika napadnut veći broj listova.
U cilju analize utjecaja položaja stabalaca u sastojini na površinu oštećenja lista od imaga i ličinke bukove skočipipe provedeno je testiranje statističke značajnosti razlika prosjeka. Utvrđeno je da prosječna površina oštećenja lista od imaga i ličinke u odnosu na prosječnu površinu lista je najveća na svjetlu, dok je kod stabalaca u sjeni nešto manja (Tablica 4). Slične rezultate je dobio i Pullin (1981) u svojim istraživanjima u Velikoj Britaniji, gdje je utvrđen veći stupanj napada i oštećenja na stablima koja su bila na svjetlu u odnosu na stabla u sjeni. Ukoliko se promatraju ova dva oštećenja vidljivo je da je u prosjeku od bukove skočipipe oštećeno od 6-10\% lisne površine stabalaca bukve. Rezultati koji su dobiveni ovim istraživanjem pokazuju da su ova oštećenja znatno veća nego u Bosni i Hercegovini (Dimitrova-Mateva 2005; 2008; Dimitrova-Mateva i dr. 2016). Utvrđivan je utjecaj položaja stabalaca bukve u sastojini na površinu oštećenja lista od imaga i ličinke (Tablica 5). Provedenim analizama je utvrđen statistički značajan utjecaj položaja stabalaca u sastojini na površinu oštećenja lista od ličinke, a nije utvrđen statistički značajan utjecaj položaja stabalaca u sastojini na površinu oštećenja lista od imaga. Istraživanjima koje je proveo Schardt i dr. $(2006$; 2008) utvrđeno je da nakon prezimljavanja imaga ovog štetnika preferiraju hranjenje listovima sjene, dok imaga nove (ovogodišnje) generacije (iste godine) preferiraju hranjenje listovima svjetla. Potrebno je monitoringom utvrđivati štetnost ovog a i svih ostalih defolijatora na područjima gdje se javlja bukva, a u cilju sprječavanja nastanka većih šteta.

\section{ZAKLJUČCI CONCLUSIONS}

$\mathrm{Na}$ osnovi provedenog istraživanja mogu se donijeti sljedeći zaključci:

- Na lokaciji gospodarske jedinice "Gornja Stavnja", odjel 30 zbog nadmorske visine (odnosno kašnjenja vegetacijskog perioda) utvrđeno je da štetnik u 2017. godini započeo stadij jajeta, ličinke, kukuljice i imaga 15 dana kasnije u odnosu na druge dvije lokacije;

- Prosječna površina oštećenja lista od imaga je znatno veća u novoj (ovogodišnjoj) generaciji, dok prosječna površina 
oštećenja lista od ličinke progresivno raste do mjeseca lipnja, nakon čega počinje blago opadati;

- Prosječna površina oštećenja lista od imaga u odnosu na prosječnu površinu lista najveća je na lokaciji gospodarske jedinice "Gornja Stavnja", odjel 30, a prosječna površina oštećenja lista od ličinke na lokaciji gospodarska jedinica „Donja Stavnja“, odjel 61;

- Utjecaj lokacije nema utjecaj na površinu oštećenja lista od imaga i ličinke;

- Površine oštećenja listova od imaga i ličinke izvan visokih šuma bukve veće su jer se radi o mješovitim šumama, a veći broj listova na tim stablima napadnut je zbog nedostatka stabala bukve uslijed prenamnoženja ovog štetnika;

- Prosječna površina oštećenja lista od imaga i ličinke u odnosu na prosječnu površinu lista najveća je na svjetlu, dok je kod stabalaca u sjeni bila nešto manja;

- Položaj stabalaca u sastojini na površinu oštećenja lista od ličinke ima značajan utjecaj, dok položaj stabalaca u sastojini nema utjecaj oštećenja od imaga.

\section{LITERATURA}

\section{REFERENCES}

- Ballian, D., B. Jukić, B. Balić, D. Kajba, G. von Wüehlisch, 2015: Fenološka varijabilnost obične bukve (Fagus sylvatica L.) u međunarodnom pokusu provenijencija. Šumarski list, 11-12, pp. 521-533.

- Dimitrova-Mateva, P., 2005: Significance and distribution of leaf insects pests on Common beech Fagus sylvatica in Training and Experimental Forest Range 'Petrohan'. Student conference 'Protection of Biodiversity and Management of Protected Areas. pp. 40-50.

- Dimitrova-Mateva, P., 2008: Leafminer insects on the Common beech (Fagus sylvatica L.) in Western Bulgaria. PhD Thesis. pp. 150 .

- Dimitrova-Mateva, P., S. Anev, S. Georgieva, G. Chaneva, N. Tzvetkova, 2016: Ecophysiological method for assessment of Orchastes fagi L. infestation on common beech trees. Forestry ideas. Vol. 22, No. 1. pp. 35-41.
- Fleming, R., W. Volney, 1995: Effects of climate change on insect defoliator population processes in Canada's boreal forest: some plausible scenarios. Water Air Soil Pollut. 8, 445-454.

- Fraser, R., R. Latifovic, 2005: Mapping insect-induced tree defoliation and mortality using coarse spatial resolution satellite imagery. Int. J. Remote Sens. 26, 193-200.

- Hartmann, G., F. Nienhaus, H. Butin, 2007: Atlas šumskih oštećenja, Eugen Ulmer, Stuttgart, Germany., ITD Gaudeamus d.o.o. (prevod), pp. 1-266.

- Metzler, B., T. Bublitz, 2004: Der Buchenspringrüssler (Rhynchaenus fagi L., syn. Orchestes fagi L.). Waldschutz-info. pp. 1-4.

- Morrison, C. D., N. M. Tainton, 1993: The effect of defoliation and competition on the regrowth of Themeda triandra and Aristida junciformis subsp. junciformis, Afr J Range For Sei 10 (3), pp. 124-128.

- Pullin, A. S., 1981: Observations on the development and mortality factors in the leaf mining stage of the beech weevil Rhynchaenus fagi L., Durham theses, Durham University. pp. 1-77.

- Rullán-Silva, C., A. E. Olthoff, V. Pando, J. A. Pajares, J. A. Delgado, 2015: Remote monitoring of defoliation by the beech leafmining weevil Rhynchaenus fagi in northern Spain. Forest Ecology and Management 347. pp. 200-208.

- Schardt, M., M. Fauster, A. Gruppe, R. Schopf, 2006: Einfluss der Blattposition auf Befallshäufigkeit und Entwicklungserfolg von Rhynchaenus fagi L. (Coleoptera: Curculionidae) an Buche (Fagus sylvatica L.). Mitt. Dtsch. Ges. Allg. Angew. Ent. 15. pp. 41-44.

- Schardt, M., A. Gruppe, R. Schopf, 2008: Nischensicherung durch monophage Herbivore. Mitt. Dtsch. Ges. Allg. Angew. Ent. 16. pp. 273-276.

- Seletković, I., N. Potočić, 2004: Oštećenost šuma u Hrvatskoj u razdoblju od 1999. do 2003. godine. Šumarski list br. 3-4. pp. 137-148.

- Tomiczek, C., D. Diminić, T. Cech, B. Hrašovec, H. Krehan, M. Pernek, B. Perny, 2007: Bolesti i štetnici urbanog drveća. Šumarski institut Jastrebarsko. Šumarski fakultet Sveučilišta u Zagrebu. pp. 1-384.

- Zúbrik, M., A. Kunca, G. Csóka, 2013: Insects and Diseases Damaging Trees of Europe. N.A.P. Éditions. A colour atlas. pp. $1-535$.

\section{SUMMARY}

The impact of beech weevil on the damaged area of beech trees from adult and larvae was analyzed, depending on the location and position of trees of beech in stand (sun/shadow). The research localities were located within the forest plantation of spruce, natural beech forests and mixed beech, fir and spruce forests. Beech weevil represents one of the main defoliators appearing on beech trees. The research sample consists of 15 beech trees, 5 trees per location, on three locations. On each location, were selected 3 trees with the crown in the sun and 2 trees with the crown in the shade (a total of 9 trees in the sun and 6 trees in the shade). On each tree were measured damages from the adult and larvae of beech weevil. It has been found that the average damaged area on beech leaf varied for adult from $2-4 \%$, and larvae $4-8 \%$. Statistical analysis showed a statistically significant differences in damaged areas of beech leaf from larvae, depending on the position of beech trees in the stand.

KEY WORDS: Fagus sylvatica, Rhynchaenus fagi, damaged area, locality, sun, shade. 